\title{
Persepsi Pelaku Bisnis UMKM Terhadap Standar Akuntansi Keuangan Entitas Mikro Kecil Dan Menengah Pada UMKM Industri Konveksi Desa Botoran, Tulungagung
}

\author{
Mutiara Rachma Ardhiani \\ Prodi Akuntansi, Universitas PGRI Adi Buana, Indonesia. \\ e-mail : mutiara@unipasby.ac.id
}

\begin{abstract}
Abstrak
Penelitian ini bertujuan untuk mengetahui dan menganalisis persepsi pelaku bisnis UMKM industri konveksi Desa Botoran, Tulungagung terhadap SAK EMKM. Teknik dokumentasi, observasi, dan wawancara dilakukan untuk mengumpulkan data. Selanjutnya, interactive model of analysis digunakan untuk menganalisis data. Hasil penelitian menemukan bahwa pelaku UMKM industri konveksi Desa Botoran, Tulungagung belum seluruhnya menerapkan SAK EMKM sehingga laporan keuangan yang dihasilkan masih belum wajar dan tidak komparatif.

Kata Kunci: SAK EMKM, Pelaku UMKM, Standar Akuntansi Keuangan, Lapora Keuangan, Industri Konveksi

Perceptions Of MSME Business Actors Against Financial Accounting Standards For Micro, Small And Medium Entities In The UMKM Convection Industry In Botoran Village, Tulungagung
\end{abstract}

\begin{abstract}
This study aims to determine and analyze the perceptions of SMEs business actors in the convection industry in Botoran Village, Tulungagung on SAK EMKM. Documentation, observation, and interview techniques were used to collect data. Furthermore, interactive models of analysis are used to analyze the data. The results of the study found that the SMEs in the convection industry in Botoran Village, Tulungagung had not entirely implemented SAK EMKM so that the resulting financial reports were still not fair and not comparative.
\end{abstract}

Keywords: SAK EMKM, MSME, Financial Accounting Standards, Financial Report, Convection Industry

\section{Pendahuluan}

Perusahaan didirikan dengan tujuan tertentu yang secara substansi tidak banyak berbeda, yaitu mendapatkan keuntungan. Hal serupa juga berlaku bagi perusahaan Usaha Mikro Kecil Menengah (UMKM). Sebagian besar masyarakat Indonesia merupakan pelaku UMKM dalam menjalankan kegiatan ekonomi dan meningkatkan kesejahteraan hidupnya. Kontribusi UMKM bagi Indonesia selain meningkatkan pendapatan adalah sebagai penyedia lapangan kerja. UMKM memiliki peran penting dalam mendukung ekonomi suatu negara (Ha, Lo, \& Wang, 2016). Pentingnya peranan tersebut memerlukan pemberdayaan dan pengembangan yang berkelanjutan bagi UMKM agar mereka tetap berkembang dari segi kualitas produk maupun daya saingnya.

UMKM dapat menjadi peluang bagi negara dalam meningkatkan pendapatan, namun dalam kegiatan operasi UMKM tak jarang mereka menghadapi beberapa kesulitan. Salah satu kesulitan yang kerap dialami para UMKM adalah kesulitan dalam menilai dan mengukur segala aktivitas yang dilakukan untuk memperoleh pendapatan yang sesungguhnya dari kegiatan usahanya. Hal ini dikarenakan para UMKM hanya melakukan proses pencatatan. Proses ini dilakukan dengan hanya

DOI: 10.25273 /inventory.vxix.8370

Copyright (C) 2021 Penulis

Sume rights reserved. 
memperhitungkan selisih uang masuk dan keluar. Proses ini tidak melihat alokasi pengeluaran sehingga sulit untuk membedakan pengeluaran dalam kegiatan usaha atau non-usaha. Hal ini menunjukkan bahwa kebanyakan UMKM menghitung harta sebatas kas yang dimiliki, padahal harta memiliki arti yang lebih luas dari itu (Suryo, 2006). Pelaku UMKM juga menganggap bahwa usaha mereka berhasil jika pendapatan saat ini lebih tinggi daripada sebelumnya. Hal ini juga dinilai kurang tepat karena untuk mengukur keberhasilan usaha perlu mengukur dan mengelompokkan transaksi selama kegiatan usaha dan mengikhtisakan seluruh transaksi itu, bukan hanya dilihat dari besarnya jumlah pendapatan.

Kesulitan lain yang dihadapi UMKM terdapat pada proses administrasi. Hal ini terjadi ketika UMKM mengajukan kredit pada bank. Salah satu syarat yang kerap ada pada saat mengajukan kredit ke bank adalah menyertakan laporan keuangan. Syarat ini diberlakukan karena bank ingin menghindari risiko dalam penyaluran kredit kepada UMKM yang tidak berkembang. Persyaratan ini menjadi masalah karena hampir semua UMKM tidak memiliki laporan keuangan. Jika pun ada, laporan keuangan UMKM menerapkan akuntansi dengan sangat terbatas. Hal ini terjadi karena pengetahuan pelaku UMKM tentang akuntansi masih kurang dan tidak terbiasa melakukan pencatatan dan membuat laporan keuangan. Selain bank, beberapa pihak yang juga meminta laporan keuangan sebagai syarat administrasi adalah rekanan yang membuka lelang pengadaan barang atau jasa dimana UMKM itu akan mengikuti proses itu. Pencatatan yang biasa dilakukan UMKM hanya mencatat jumlah uang masuk dan keluar, jumlah pembelian dan penjualan barang, serta jumlah utang dan piutang. Namun, pencatatan itu pun hanya berfungsi sebagai pengingat (Fitriasuri \& Terizaghi, 2015; Mwangi, 2011) dan tidak sesuai dengan format yang diinginkan bank maupun rekanan. Beberapa hal tersebut menunjukkan laporan keuangan yang baik dan sesuai standar diperlukan UMKM agar dapat bertahan dan berkembang dalam dunia bisnis.

Laporan keuangan diharapkan dimiliki oleh setiap unit usaha. Laporan ini menyajikan berbagai informasi keuangan perusahaan seperti laba rugi dan perubahan arus kas. Informasi tersebut selanjutnya berfungsi sebagai dasar untuk menganalisis kinerja yang telah dilakukan sebagai dasar untuk mengambil keputusan, baik secara finansial maupun manajemen sebagai sarana pertanggungjawaban. Rendahnya praktik akuntansi pada UMKM disebabkan karena terdapat beberapa kelemahan antara lain karena pendidikan yang rendah, pelatihan dan pemahaman mengenai standar akuntansi dari pemiliki UMKM yang kurang, serta tidak ada peraturan yang mewajibkan UMKM untuk selalu membuat laporan keuangan (Uyar \& Güngörmüs, 2013; Wahdini \& Suhairi, 2006)

Penerapan akuntansi dimulai dari proses penyusunan laporan keuangan. Laporan tersebut akan menghasilkan informasi-informasi yang berperan penting dalam proses penyusunan berbagai rencana perusahaan, pengendalian, maupun berbagai pengambilan keputusan. Setiap UMKM diharapkan mampu membuat laporan sesuai dengan standar umum yang diakui oleh berbagai pihak, misalnya bank maupun rekanan lain, dalam rangka mengembangkan usaha. Berdasarkan hal tersebut, maka perlu dibiasakan bagi para pengusaha UMKM agar secara rinci mencatat setiap kegiatan usaha dan menyusunnya menjadi laporan keuangan.

Ikatan Akuntan Indonesia (IAI) menyadari kesulitan yang dialami UMKM sehingga mengesahkan standar yang ditujukan untuk UMKM yaitu Standar Akuntansi Keuangan Entitas Mikro Kecil dan Menengah (SAK EMKM). Pembuatan standar ini ditujukan kepada entitas mikro dan kecil agar dapat menyediakan informasi keuangan yang dapat memudahkan pengguna (misalnya kreditur maupun investor) dalam pengambilan keputusan ekonomi. Tujuan dari diterbitkannya SAK EMKM adalah memudahkan UMKM dalam membuat laporan keuangan yang berguna dalam memperoleh pendanaan dan pengembangan usaha.

Penelitian ini bertujuan untuk mengetahui dan menganalisis persepsi pelaku bisnis UMKM industri konveksi Desa Botoran, Tulungagung terhadap SAK EMKM. Desa Botoran, Tulungagung merupakan kawasan UMKM industri konveksi. Baju muslim anak merupakan salah satu produk UMKM desa Botoran. Hasil produksi didistribusikan ke berbagai daerah, mulai dari Tulungagung, Trenggalek, Blitar, Pasuruan, serta beberapa daerah di Jawa Tengah dalam jumlah yang cukup besar. Namun beberapa UMKM mengalami kesulitan dalam menyusun laporan keuangan ketika memerlukan pinjaman ke bank. Sering kali karena tidak dapat memenuhi syarat tersebut, UMKM yang kekurangan dana menjadi sulit berkembang, bahkan beberapa diantaranya gulung tikar. Beberapa hal tersebut menunjukkan pentingnya laporan keuangan bagi UMKM untuk menunjang keberlangsungan bisnis mereka. 


\section{Metode Penelitian}

Tujuan penelitian ini adalah untuk mengetahui dan menganalisis persepsi pelaku UMKM industri konveksi di Desa Botoran, Tulungagung. Pendekatan kualitatif dilakukan untuk memahami fenomena yang terjadi pada subjek penelitian. Pendekatan ini menggunakan pemahaman holistik dan dideskripsikan dalam bentuk kalimat dengan berbagai metode ilmiah. Penelitian menggunakan data primer yang bersumber dari wawancara dengan pihak yang berhubungan dengan penelitian seperti pemilik atau bagian keuangan. Selain itu, data sekunder berupa dokumen dan informasi perusahaan khususnya informasi keuangan juga digunakan dalam penelitian ini.

Data dikumpulkan dengan teknik observasi, wawancara, dan dokumentasi. Obeservasi dilakukan untuk menggali data yang bersumber dari fenomena, tempat, dan benda. Proses psikologis diperlukan dalam melakukan teknik ini. Penelitian ini akan melakukan observasi terkait pencatatan keuangan pada industri konveksi di Desa Botoran, Tulungagung. Wawancara dilakukan melalui proses tanya jawab antara peneliti dengan para pelaku bisnis UMKM industri konveksi Desa Botoran, Tulungagung. Wawancara dilakukan secara informal untuk menggali hal-hal yang sifatnya umum, dan secara terstruktur dengan petunjuk wawancara untuk menggali hal-hal yang berkaitan dengan pencatatan yang mereka lakukan. Informan dalam penelitian ini adalah sebanyak enam pelaku UMKM industri konveksi. Mereka adalah Chusbaniyah, Joko, Lilik, Istifadah, Kholis, dan Anisah. Teknik terakhir yang akan dilakukan adalah dokumentasi. Teknik ini merupakan proses pencarian data melalui dokumen-dokumen yang relevan (Arikunto, 2006:231). Penelitian ini menggunakan dokumen berupa berbagai catatan transaki, laporan keuangan, serta peraturan yang relevan seperti SAK EMKM dan UU UMKM. Data yang telah terkumpul selanjutnya dianalisis dengan interactive model of analysis. Teknik ini menggali data dari narasumber secara terus menerus dan interaktif hingga datanya jenuh (Sugiyono, 2010:246).

Usaha mikro kecil dan menengah terdiri dari berbagai sektor industri, salah satunya industri konveksi. Para pelaku UMKM pada sektor ini telah melakukan pembukuan dalam kegiatan usahanya. Pembukuan yang mereka lakukan sangatlah sederhana dan tidak meng acu pada format atau standar tertentu yang berlaku umum.

Pembukuan sangat sederhana yang mereka lakukan sering menimbulkan kesulitan ketika mengajukan pendanaan pada pihak penyalur dana maupun mengikuti lelang karena mengharuskan adanya laporan keuangan sebagai salah satu syarat. Menyikapi hal tersebut, IAI mengeluarkan SAK EMKM yang dapat menjadi pedoman para UMKM dalam menyusun laporan keuangan. Berdasarkan pemaparan tersebut, peneliti ingin mengevaluasi perlaksanaan SAK EMKM pada UMKM industri konveksi. Di samping itu, berbagai penelitian dari berbagai dunia yang meneliti akuntansi dalam industri UMKM menunjukkan pentingnya penerapan suatu standar akuntansi pada industri ini untuk keberlangsungan usaha mereka.

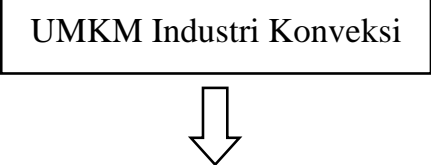

Pembukuan sederhana yang telah dilakukan oleh pelaku UMKM sering tidak sesuai dengan standar yang diinginkan kreditur atau investor sehingga menghambat mereka dalam mendapatkan tambahan dana untuk pengembangan usaha

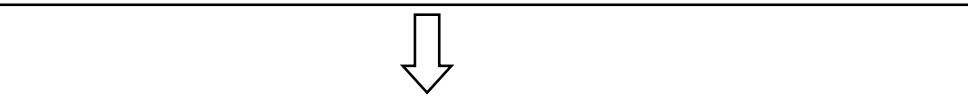

Penyusunan Laporan Keuangan berdasarkan SAK EMKM

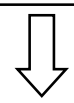

a. Laporan Posisi Keuangan

b. Laporan Laba Rugi

c. Catatan Atas Laporan Keuangan

Gambar 1. Kerangka Pemikiran 
Laporan keuangan dibuat dengan maksud untuk menyajikan informasi kinerja keuangan suatu entitas, dimana informasi ini dapat dijadikan dasar untuk pengambilan keputusan baik keuangan maupun nonkeuangan, serta mempertanggungjawabkan kinerja manajemen. Laporan keuangan harus menyajikan pos-pos seperti :

a. Aset, yang diakui ketika masih memiliki manfaat ekonomi bagi entitas di masa depan dan biaya yang melekat pada aset itu bisa diukur secara handal. Apabila terjadi suatu pengeluaran namun tidak memiliki manfaat ekonomi, maka pengeluaran tersebut tidak diakui sebagai aset melainkan sebagai beban yang disajikan dalam laporan laba rugi.

b. Liabilitas, yang diakui dan dicatat sejumlah dengan yang harus dibayarkan. Pengakuan ini dapat dihentikan apabila pembayaran liabilitas tersebut telah lunas atau diselesaikan dengan cara lain yang sah secara hukum oleh kedua belah pihak.

c. Penghasilan, yang diakui apabila terdapat kenaikan manfaat ekonomi yang terjadi akibat kenaikan aset atau penurunan liabilitas. Penghasilan ini diukur secara handal dan disajikan pada laporan laba rugi.

d. Beban, yang diakui apabila terdapat penurunan manfaat ekonomi yang terjadi akibat penurunan aset atau kenaikan liabilitas. Seperti halnya penghasilan, beban diukur secara handal da tersaji dalam laporan laba rugi.

SAK EMKM mengatur mengenai laporan yang harus terdapat laporan keuangan. Laporan-laporan tersebut meliputi :

a. Laporan posisi keuangan. Laporan ini minimal harus menyajikan informasi atas kas dan setara kas, piutang, persediaan, aset tetap, utang usaha dan bank, serta ekuitas. Penggunaan format tertentu tidak diatur dalam SAK EMKM, namun entitas dapat mengurutkan dengan dasar likuiditas untuk pos aset dan jatuh tempo untuk pos ekuitas.

b. Laporan laba rugi. Laporan ini menyajikan informasi berupa pendapatan dan beban keuangan termasuk beban pajak pada satu periode. Laporan ini disajikan secara relevan agar pengguna dapat memahami kinerja entitas dari segi keuangan.

c. Catatan Atas Laporan Keuangan (CALK). Laporan ini menyajikan pernyataan bahwa laporan keuangan telah disusun dan disajikan berdasarkan SAK EMKM, informasi mengenai kebijakan akuntansi. Selain itu, CALK juga harus memberikan penjelasan secara detail untuk setiap pos di laporan keuangan. Penyajian CALK disesuaikan dengan jenis usaha perusahaan.

Persepsi adalah penafsiran dan pemberian arti yang dilakukan oleh individu terhadap segala hal yang terjadi di lingkungan atas manfaat yang akan diperolehnya (Utaminingsih, 2014: 18). Persepsi dibentuk oleh proses kognitif dan kenyataan, namun kegiatan kognitif lebih dominan (Lubis, 2011). Kesadaran, pikiran, ingatan, dan bahasa mempengaruhi terbentuknya persepsi. Persepsi menjadi awal dari proses penilaian sesuatu sehingga bukan cerminan yang tepat atas realita (Hani, 2012:2). Seseorang yang ingin memperoleh manfaat dari suatu peristiwa atau objek akan melakukan proses penafsiran, pemberian makna berdasarkan panca indera masing-masing.

Faktor fungsional dan struktural merupakan dua faktor pembentuk persepsi (Rakhmat, 2007). Faktor fungsional dalam penentuan persepsi berasal dari objek yang memnuhi tujuan individu yang meliputi kebutuhan, keinginan, harapan, perhatian, nilai, emosi dan suasana hati, serta pengalaman masa lalu. Di sisi lain, faktor struktural dibentuk stimulus fisik masing-masing individu. Persepsi dipengaruhi oleh beberapa indikator sebagai berikut :

a. Seleksi (selection) merupakan proses memperhatikan suatu objek menggunakan panca indera.

b. Organisasi dan pemberian makna (organization). Informasi yang telah didapatkan dipilah menjadi suatu hal yang bermakna.

c. Interpretasi dan penilaian (interpretation). Informasi yang telah dipilah akan diberi makna agar dapat dimengerti melalui proses penjelasan dengan bahasa (Sobur, 2013:447).

Indikator-indikator di atas menjadi dasar untuk mengembangkan instrumen wawancara mengenai persepsi pelaku UMKM tentang SAK EMKM seperti berikut:

1. Penyeleksian akuntansi bagi pelaku UMKM berdasarkan panca indera mereka. Contohnya adalah bagi pelaku UMKM, akuntansi adalah proses pencatatan keuangan.

2. Pemahaman dan pemberian arti akuntansi bagi pelaku UMKM setelah proses pengamatan. Contohnya adalah hasil dari proses akuntansi adalah informasi keuangan usaha UMKM. 
3. Penginterpretasian dan penilaian akuntansi bagi pelaku UMKM secara keseluruhan terjadap akuntansi. Contohnya adalah pengambilan keputusan bisnis berdasarkan informasi laporan keuangan UMKM.

\section{Hasil Dan Pembahasan}

Laporan keuangan dibuat dengan tujuan agar entitas bisnis dapat mengetahui posisi keuangan, laba rugi, dan arus kas perusahaan. Laporan keuangan harus disajikan secara wajar, dimana kejujuran menjadi dasar untuk penyajian setiap transaksi dan peristiwa dalam pengakuan aset, kewajiban, modal, pendapatan, maupun beban (Shonhadji, et al., 2017). Penerapan SAK EMKM diharapkan dapat menghasilkan laporan keuangan yang wajar bagi entitas UMKM. UMKM dapat memberikan pengungkapan tambahan jika terdapat ketentuan SAK EMKM yang tidak memadai untuk dipahami oleh pengguna dalam memahami informasi laporan keuangan.

Hasil wawancara dengan enam pelaku UMKM industri konveksi Desa Botoran, Tulungagung diketahui bahwa terdapat satu pelaku UMKM yang membuat laporan keuangan. Sedangkan, pelaku UMKM lainnya melakukan pencatatan transaksi tanpa membuat laporan keuangan. Kelima pelaku UMKM membuat catatan keuangan berdasarkan kebutuhan mereka masing-masing karena belum memahami SAK EMKM. Berdasarkan catatan keuangan tersebut mereka merasa mendapatkan informasi yang cukup mengenai kondisi keuangannya. Informasi keuangan yang dihasilkan pun tidak wajar karena mereka hanya berfokus pada laba dan rugi. Hal lain seperti pengakuan aset, kewajiban, modal, pendapatan, dan beban tidak mendapatkan perhatian.

... Saya rasa belum perlu (melakukan pencatatan lengkap). Soalnya dari

catatan saya yang seperti biasanya itu saya sudah bisa tau untung atau

ruginya. Jadi saya rasa cukup (Informan Joko, 10 Mei 2020).

Pemerintah menyadari pentingnya penggunaan standar keuangan pada sektor UMKM. Pemerintah melalui Dinas Koperasi dan UMKM Tulungagung telah melakukan penyuluhan mengenai SAK EMKM, namun masih belum mampu menimbulkan keinginan pelaku UMKM industri konveksi Desa Botoran, Tulungagung untuk menerapkan standar akuntansi. Hal itu disebabkan ketidakmampuan pelaku UMKM dalam menerapkan standar tersebut. Mereka merasa tertinggal dalam mengikuti kemajuan jaman, khususnya teknologi. Standar akuntansi bahkan dipandang sebagai suatu hal yang justru menyusahkan mereka. Standar akuntansi menjadi tantangan tersendiri bagi UMKM untuk diterapkan (Perera \& Chand, 2015).

Dulu pernah ada (penyluluhan). Malah tambah bingung saya. Banyak tabeltabelnya. Istilahnya juga macam-macam ... Akhirnya tetap nyaman pakai buku tulis kalau catat-catat (transaksi) (Informan Chusbaniyah, $9 \mathrm{Mei}$ 2020).

SAK EMKM mengatur bahwa laporan keuangan entitas lengkap meliputi Laporan Posisi Keuangan, Laporan Laba Rugi, dan Catatan Atas Laporan Keuangan (SAK EMKM, 2016). Hasil wawancara dengan enam pelaku UMKM industri konveksi yang ada di Desa Botoran, Tulungagung diketahui bahwa terdapat satu pelaku UMKM yang membuat laporan keuangan, yaitu Lilik Diana, sedangkan pelaku UMKM lainnya hanya melakukan pencatatan transaksi tanpa membuat laporan keuangan. Lilik menggunakan jasa konsultan keuangan utnuk membantunya menyusun laporan keuangan. Pelaku UMKM lain yang juga menggunakan jasa konsultan adalah Nur Kholis. Berbeda dengan Lilik yang menggunakan jasa konsultan untuk keseluruhan usaha, Nur Kholis hanya menggunakan jasa konsultan untuk keperluan perpajakannya.

... Saya betulkan di konsultan ... Sangat membantu sekali soalnya. Keuangan jadi lebih terkontrol (Informan Lilik, 23 Mei 2020).

Entitas bisnis harus menyajikan laporan keuangan minimal setiap satu tahun sekali agar menghasilkan informasi yang komparatif. Pencatatan transaksi sebaiknya dilakukan setiap saat ketika terjadi transaksi untuk menghindari informasi yang terlewat. Hasil penelitan mengungkapkan bahwa pencatatan keuangan pelaku UMKM industri konveksi Desa Botoran, Tulungagung melakukan pencatatan secara harian, mingguan, bulanan, bahkan tidak rutin melakukan pencatatan. Keterbatasan sumber daya manusia menjadi salah satu penyebabnya. Selain itu, atas catatan transaksi keuangan tersebut tidak dilakukan identifikasi lebih lanjut.

Untuk pencatatan masih belum teratur karena terkadang kalau ada pembelian atau penjualan saya lupa mencatat dan baru beberapa hari gitu saya catat (Informan Istifadah, 24 Mei 2020). 
Penyajian dan klasifikasi pos-pos pada laporan keuangan harus konsisten tiap periodenya. Apabila terdapat perubahan, maka perlu dilakukan reklasifikasi jumlah komparatif. Reklasifikasi dapat tidak dilakukan apabila dalam melakukannya tidak praktis. Hasil penelitian menunjukkan bahwa sebagian besar narasumber UMKM industri konveksi Desa Botoran masih belum konsisten dalam melakukan pencatatan keuangan. Penyebabnya adalah mereka tidak memperhatikan tata cara dan aturan pencatatan keuangan. Selain itu, masing-masing pelaku UMKM memiliki cara mencatat yang berbeda tergantung pada kebutuhan informasi dan kreatifitas mereka.

Biasanya (catatan keuangan) buat lihat daftar orang-orang yang masih ada utang ke saya. Saya lihat rinciannya. Kalau sudah jatuh tempo berarti waktunya saya tagih (utangnya) (Informan Nur Kholis, 6 Juni, 2020).

Informasi keuangan harus dapat diperbandingkan (komparatif) dengan periode sebelumnya. Hal ini bertujuan agar pengguna informasi dapat menilai adanya kenaikan atau penurunan kinerja entitas secara keseluruhan. Entitas dapat menyajikan informasi naratif dan deskriptif yang relevan guna meningkatkan pemahaman pengguna terkait informasi keuangan selama periode berjalan. Hasil penelitian mengungkapkan bahwa sebagian besar informasi keuangan pelaku UMKM industri konveksi Desa Botoran tidak komprataif karena tidak ada standar yang digunakan dalam laporan keuangan mereka. Sebagian besar informan menganggap bahwa informasi keuangan bukan hal penting dalam pengambilan keputusan bisnis, melainkan hanya sebagai pengingat. Bagi mereka, informasi keuangan hanya sebatas untuk mengetahui jumlah laba atau rugi dan hal itu dilihat dari aktifitas operasional. Berdasarkan hal itu, pelaku UMKM merasa belum membutuhkan laporan keuangan secara lengkap.

Bagi saya laporan keuangan itu ya untuk mengetahui jumlah berapa uang keluar sama masuk, terus ketemu untung atau ruginya (Informan Anisah, 7 Juni 2020).

\section{Kesimpulan Dan Saran}

Berdasarkan dari hasil penelitian dapat disimpulkan bahwa pelaku UMKM industri konveksi Desa Botoran, Tulungagung belum seluruhnya menerapkan SAK EMKM. Hal ini dikarenakan keterbatasan sumber daya manusia sehingga standar ini dianggap menyulitkan mereka, belum adanya pemisahan antara aset pribadi dan aset perusahaan, pencatatan transaksi keuangan yang belum rutin, serta merasa belum membutuhkan informasi lengkap dari laporan keuangan.

Jika dilihat dari kewajaran laporan keuangan, maka laporan keuangan pelaku UMKM industri konveksi Desa Botoran, Tulungagung masih belum wajar. Selain itu, informasi yang diberikan tidak komparatif karena tidak menerapkan standar apapun. Pelaku UMKM hanya membutuhkan informasi keuangan hanya untuk mengetahui laba atau rugi dari kegiatan operasional mereka.

SAK EMKM merupakan tantangan tersendiri untuk diterapkan pada UMKM industri konveksi Desa Botoran, Tulungagung. Oleh karena itu, peneliti menyarankan agar dilakukan pelatihan dan pendampingan pencatatan keuangan sesuai SAK EMKM kepada pelaku UMKM di Tulungagung, khususnya pada industri konveksi Desa Botoran, Tulungagung.

\section{Daftar Pustaka}

Arikunto, S. (2006). Prosedur Penelitian Suatu Pendekatan Praktik.Jakarta: Rineka Cipta

Fitriasuri, \& Terizaghi, M. T. (2015). Akuntansi Pada Pengusaha UKM Industri Kreatif: Kesiapan SDM dalam Menghadapi Globalisasi. Jurnal Ilmiah MBiA, 14(2), 75-84.

Ha, S., Lo, M., \& Wang, Y. (2016). Relationship between Knowledge Management and Organizational Performance: A Test on SMEs in Malaysia. Procedia - Social and Behavioral Sciences, 224, 184-189.

Hani, H. (2012). Manajemen Personalia dan Sumber Daya Manusia. Yogyakarta: BPFE.

Ikatan Akuntan Indonesia. (2017). Pernyataan Standar Akuntansi Keuangan No. 1 (Revisi 2017).

Lubis, A.I. (2011). Akuntansi Keperilakuan. Jakarta : Salemba Empat.

Mwangi, B. W. (2011). Accounting Systems in Small and Micro Enterprises in Kenya. Journal of Language, Technology \& Entrepreneurship in Africa, 3(1), 78-98.

Perera, D., \& Chand, P. (2015). Advances in Accounting, incorporating Advances in International Accounting Issues in the adoption of international fi nancial reporting standards (IFRS) for small 
and medium-sized enterprises (SMES). Advances in Accounting, Incorporating Advances in International Accounting.

Rakhmat. J. (2007). Psikologi Komunikasi. Bandung: PT Remaja Posdakarya.

Sobur, A. (2011). Psikologi Umum. Bandung: CV Pustaka Setia.

Sugiyono. (2010). Metode Penelitian Kuantitatif Kualitatif dan R\&D. Bandung: Alfabeta.

Suryo, Anak. (2006). Akuntansi untuk UKM: Metode Akuntansi Praktis dan Sederhana untuk Usaha Kecil dan Menegah. Yogyakarta: Media Pressindo.

Shonhadji, N., Laely Aghe A., Djuwito. (2017). Penerapan Penyusunan Laporan Keuangan Pada Usaha Kecil Menengah Berdasarkan Sak Emkm Di Surabaya. Seminar Nasional Hasil Pengabdian kepada Masyarakat (SENIAS). Hal. 130-136

Utaminingsih, A. (2014). Perilaku Organisasi. Malang: UB Press.

Uyar, A., \& Güngörmüs, A. H. (2013). Research in Accounting Regulation Perceptions and knowledge of accounting professionals on IFRS for SMEs : Evidence from Turkey. Research in Accounting Regulation, 25, 77-87.

Wahdini \& Suhairi. (2006). Persepsi Akuntan Terhadap Overload Standar Akuntansi Keuangan (SAK) Bagi Usaha Kecil Dan Menengah. SNA IX - Padang. 